NBSIR 86-3397

\title{
Executive Summary - Conference on Accreditation of Construction Materials Testing Laboratories, May 14-15, 1986
}

James H. Pielert

U.S. DEPARTMENT OF COMMERCE

National Bureau of Standards

Center for Building Technology

Construction Materials Reference Laboratories

Building Materials Division

Gaithersburg, MD 20899

June 1986

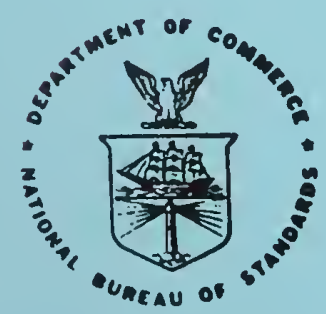

U.S. DEPARTMENT OF COMMERCE

$Q C$

NAL BUREAU OF STANDARDS

100

.056

86-3397

1986

C. 2 

EXECUTIVE SUMMARY - CONFERENCE ON ACCREDITATIONOF CONSTRUCTION MATERIALS TESTING LABORATORIES, MAY 14-15, 1986

James H. Pielert

U.S. DEPARTMENT OF COMMERCE

National Bureau of Standards

Center for Building Technology

Construction Materials Reference Laboratories

Building Materials Division

Gaithersburg, MD 20899

June 1986

U.S. DEPARTMENT OF COMMERCE, Malcolm Baldrige, Secretary NATIONAL BUREAU OF STANDARDS, Ernest Ambler, Director 



\section{Abstract}

A two-day Conference hosted by NBS was held in Gaithersburg, Maryland on May 14-15, 1986 to test the hypothesis that "There is a need for a coordinated methodology for accrediting construction materials testing laboratories." Construction materials include primary materials such as: cement, concrete, aggregates, rock and soil, asphalts, metals, wood and masonry. The Conference was structured to consider: (1) the status of existing laboratory evaluation and accreditation programs; (2) current trends in the accreditation process; and (3) the need for and nature of a coordinated accreditation system. The Conference included the presentation of invited papers and four workshop sessions. This Executive Summary presents the findings and proposed actions of the workshops and the Conference recommendations. Conference proceedings will be published later.

Key Words: accreditation; building; construction; evaluation; laboratory; materials; standards 
Table of Contents

Page

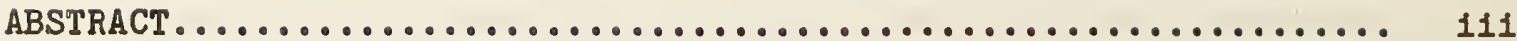

1. Introduction and Background........................ 1

2. Purpose and Organization of the Conference................ 2

3. Workshop Findings and Proposed Actions.................. 4

3.1 Workshop I................................ 4

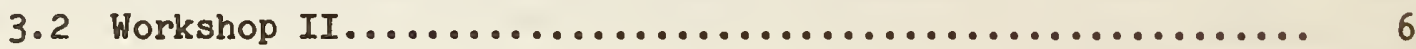

3.3 Workshop III............................. 7

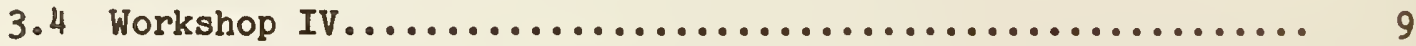

4. Recommendations of the Conference.................... 10

Appendix A: Conference Organizing Committee.............. A-1

Appendix B: Conference Program..................... B-1

Appendix C: Conference Registrants..................... C-1

Appendix D: Guidelines for Workshop Chairmen............. D-1 
A Conference on Accreditation of Construction Materials Testing Laboratories was hosted by the National Bureau of Standards (NBS) in Gaithersburg, Maryland on May 14-15, 1986. The Conference was sponsored by the:

American Society for Testing and Materials

American Association of State Highway and Transportation Officials

American Concrete Institute

American Council of Independent Laboratories

Florida Concrete and Products Association.

The Cement and Concrete Reference Laboratory (CCRL) is an NBS Research Associate Program sponsored by ASTM Committees $\mathrm{C}-1$ on Cement and $\mathrm{C}-9$ on Concrete and Concrete Aggregates. CCRL is organizationaliy located in the NBS Center for Building Technology, which manages its day-to-day operations. Policy oversight is provided to CCRL by a Joint ASTM C1/C9 Subcommittee on the CCRL. This Joint subcommittee is studying the possibility of accrediting laboratories and in September 1985 made a recommendation to the ASTM Board of Directors that:

1. CCRL programs be extended to include laboratory accreditation within the framework of ASTM, and

2. If ASTM allows the Joint Subcommittee and CCRL to proceed with laboratory accreditation, ASTM should work with NBS to revise the .anolarge policy established at the formation of CCRL in 1929 which specified that CCRL would not certify laboratories.

While this recommendation was being considered by ASTM, the Joint Subcommittee initiated plans for this National Conference to address the overall question of accreditation of construction materials testing laboratories. 
The Conference Organizing Committee listed in Appendix A established the purpose and organization of the Conference, selected speakers and workshop chairmen, and prepared guidelines for workshop chairmen. NBS hosted the Conference as a service to the construction community and does not necessarily endorse the conclusions of the workshops or the Conference as a whole.

\section{PURPOSE AND ORGANIZATION OF CONFERENCE}

The Conference was organized to test the hypothesis that:

where is a need for a coordinated methodology for accrediting construction naterials testing laboratories."

Construction materials were defined for the purposes of this conference to include primary materials such as: cement, concrete, aggregates, rock and soil, asphalts, metals, wood and masonry.

The Conference was structured to consider:

1. the status of existing laboratory evaluation and accreditation programs for the primary construction materials;

2. current trends in the accreditation process; and

3. the need for and nature of a coordinated national accreditation system.

Appendix B shows the program for the Conference. The first day included the presentation of invited papers and the convening of four workshop sessions. Each workshop was asked to address the Conference hypothes1s. The workshops continued meeting on the morning of the second day to prepare reports with findings and proposed actions for presentation to all Conference partic1pants in the afternoon. The workshop reports are given in section 3 below. Appendix C lists the names and addresses of Conference registrants and 
workshop assignments. Appendix D lists the issues provided to the workshop chairmen as possible topics for discussion with the understanding that the workshops could change the list.

The following organizations are referenced in this Executive Summary:

AALA American Association for Laboratory Accreditation

AASHTO American Association of State Highway and Transportation Officials

ACI American Concrete Institute

ACIL American Council of Independent Laboratories

AIA American Institute of Architects

AMRL AASHTO Materials Reference Laboratory

ASCE American Society of Civil Engineers

ASME American Society of Mechanical Engineers

ASTM American Society for Testing and Materials

CABO Council of American Building Officials

CCRL Cement and Concrete Reference Laboratory

DoD U.S. Department of Defense

ELF/FCPA Engineering Laboratories Forum/Florida Concrete and Products Assoc.

FHWA Federal Highway Administration

GSA U.S. General Services Administration

HUD U.S. Department of Housing and Urban Development

ILAC International Laboratory Accreditation Conference

NBS National Bureau of Standards

NCSBCS National Conference of States on Building Codes and Standards

NIBS National Institute of Building Sciences

NVLAP National Voluntary Laboratory Accreditation Program

WACEL Washington Area Council of Engineering Laboratories 


\section{WORKSHOP FINDINGS AND PROPOSED ACTIONS}

The workshop assignments shown in Appendix $C$ were made on a random basis except that, where possible, individuals representing the same organization were not assigned to the same workshop. Attendance records at each workshop session were not kept, but attendance was generally less than the assigned number. Therefore, it should not be assumed that each registrant participated in the discussions resulting in the findings and proposed actions of the assigned workshop.

\subsection{WORKSHOP I. CHAIRMAN - PAUL KLIEGER 1/}

\section{Findings}

1. There is a need for a coordinated approach to the accreditation of construction materials testing laboratories. Coordination would have a significant impact in improving the quality of construction in this country.

2. CCRL and AMRL are providing the type of inspection and proficiency testing programs that ought to be included in the requirements of a laboratory accreditation system.

3. The NVLAP program is not as broad in scope as CCRL and AMRL and does not have their credibility even after about elght years of existence.

4. The AALA accreditation program for construction materials is not near the stage of development of CCRL and AMRL and would require a significant amount of time to attain their level.

5. There will be an increasing demand for laboratory accreditation since more and more specifying bodies are requiring it in contract documents.

1/ See Appendix C for affiliation of workshop chairmen 
6. The accreditation system should offer different levels of accreditation depending on the scope of activities of the particular laboratory rather than just one broad accreditation effort.

7. The initial coordinated accreditation effort should be with the primary construction materials; concrete, steel, asphalt, etc. CCRL and AMRL have well-established programs for many of these materials.

8. There is a need for some type of accreditation for project and branch laboratories.

9. Available standards for laboratory accreditation are improving rapidly (e.g. ASTM E329 Standard Recommended Practice for Inspection and Testing Agencies for Concrete, Steel and Bituminous Materials as Used in Construction), but work remains to be done to insure coverage for all primary construction materials.

10. Certificates of accreditation should be sufficiently detailed so that the client using the laboratory is made aware of the limitations and constraints put on the accreditation. Wording on the certificate can be selected to reduce the potential liability of the accrediting organization.

11. Promotion of a coordinated accreditation program could be accomplished through technical societies such as ACI, ASME, and ASCE, and through technical publications. Workshops and seminars could also be used to bring the program to the attention of specifying agencies.

\section{Action Proposed}

The first step in the consolidation and coordination of accreditation activities should be taken by CCRL and AMRL by requesting their organizational sponsors (ASTM and AASHTO) to take on the role of accreditors, possibly under 
the supervision of their oversight committees. Accreditation can best be accomplished by a voluntary consensus organization rather than either a governmental organization or a private sector organization.

\subsection{WORKSHOP II. CHAIRMAN - THOMAS FLINT}

\section{Findings}

1. There is a need for a coordinated laboratory accreditation system for the primary construction materials defined for the Conference. The individuality of organizations currently involved with accreditation such as CCRL, NVLAP, AALA and AMRL should be retained where possible.

2. Implementation of the accreditation system should be through an umbrella organization such as ASTM, AASHTO, NIBS, a U.S. conference structured similarly to ILAC, or some combination thereof.

3. Implementation of a coordinated system should attempt to minimize duplication of individual programs such as through the use of shared assessors (e.g. AALA acceptance of CCRL assessments for concrete laboratories).

4. AALA and NVLAP appear to be coming together in that both use specific test methods in evaluating the construction materials discipline.

5. Laboratory accreditation needs to cover equipment, test and operational procedures, and personnel.

6. Educational programs, seminars and publications should be used to promote accreditation along with the use of specification references and regulatory requirements.

\section{Action Proposed}

Convene a working group of organizations clearly identified as concerned with laboratory accreditation of primary construction materials to quickly follow 
up the work of this Conference. The charge to this froup should be ro define the goals, scope, format and procedures of a coordinated national accreditation system for construction materlals testing laboratories. Selected individuals and organizations should be invited to insure a continuity of consideration based on the concluslons and recommendations of this Conference. Participation in the working group should be from organizations such as AALA, NVLAP, CCRL, AMRL, ASCE, AASHTO, WACEL, ELF/FCPA, NCSBCS, CABO, ASTM, ACIL, ACI, NBS, DOD, HUD, GSA and FHWA. It is suggested that this meeting be hosted by ASTM and that Wayne E1118 be approached to serve as temporary chairman based on his previous involvement with ASTM and laboratory accreditation. Planning for this working group meeting would be carried out by the chairman and representatives of the primary organizations involved (ASTM, AASHTO, AALA and NBS). The organizing committee of this Conference should see that this meeting is held as soon as possible.

\subsection{WORKSHOP III. CHAIRMAN - EDWARD GALLOWAY}

\section{Findings}

1. There is a need for a coordinated accreditation system for the primary construction materials. This system should involve the present CCRL and AMRL programs.

2. There should only be one level of accreditation. A laboratory should not be permitted to pick and choose from anong several levels of accreditation.

3. A laboratory should be inspected every two years with an annual review of records.

4. An accreditation program should have an unbiased credibility; have knowledgeable, experienced, and professional personnel; have proper 
equipment; and possess the ability to adapt to changes in test methods.

The program should be operated on a not-for-profit basis.

5. There already are, or soon will be, sufficient standards avallable (e.g. ASTM E 329) to govern an accreditation system for the primary construction materials.

6. The time from when a laboratory requests an accreditation to the time the evaluation is made is critical and should be minimized.

\section{Actions Proposed}

1. The Federal Highway Administration and other appropriate Federal Agencies should encourage/request that state highway administrations require that all testing of primary construction materials be accomplished by accredited laboratories.

2. Building code bodies should be approached and encouraged to require the use of accredited laboratories.

3. Professional organizations such as ACI, ASCE, ASTM, AASHTO, ASME, AIA and others should be encouraged through their membership and publications to make people aware of such an accreditation system and to promote its use to the utmost.

4. Future development of accreditation systems should provide for local or state involvement in order to make these systems work.

5. NVLAP should not move forward to establish an independent laboratory accreditation program but, instead, NVLAP officials should enter the dialogue with other sponsors of this Conference and help develop a harmonized, coordinated system.

6. ASTM and sponsors of this Conference should be encouraged to continue their efforts to reach other organizations to establish policles and to 
promote the coordination of accreditation of construction materials testing laboratories. These efforts should include the accrediting of the accrediting bodies.

\subsection{WORKSHOP IV. CHAIRMAN - WILLIAM GUNDERMAN}

\section{Findings}

1. There is definitely a need for a coordinated laboratory accreditation system for the primary construction materials.

2. Problems are created by multiple standards for the same construction materials such as may occur for standards of ASTM, AASHTO, or State DoT's. 3. Periodic follow-up evaluation of laboratory performances must be part of the accreditation system.

4. The current system where a laboratory may be require to hold several evaluations and accreditations is causing problems relative to costs and impact on operations.

5. Standards for accreditation are currently well developed but procedures and acceptance levels for accrediting or disaccrediting are non-existent except for NVLAP. International standards for accreditation should be used where possible.

6. There is a need for a major educational and/or sales approach to promote acceptance of the system.

7. There should be a minimum scope of accreditation for any given material area such as concrete.

8. If CCRL and AMRL were to expand into accreditation, these services should be marketed as a joint program where applicable. It would be desirable to schedule a common visit by these two inspecting agencies.

9. The format of the accreditation certificate should be appropriate for public display, be relatively simple and, where necessary, be backed up 
with other documents such as a scope statement. The laboratory commitment should be indicated by a signature on the part of the laboratory, but not necessarily on the certificate.

10. The ideal way to gain acceptance of a coordinated accreditation system is by reference in specifications. There is a need for better dissemination of current information on laboratory inspection and accreditation systems.

\section{Action Proposed}

An executive summary of the Conference and workshops should be published and widely distributed to gain the kind of publicity needed to implement a coordinated accreditation system.

\section{RECOMMENDATIONS OF THE CONEERENCE}

After presentation of the workshop reports and extensive discussion by Conference participants, there was a strong consensus on the following two issues:

1. There is a need for a coordinated national system for the accreditation of construction materials testing laboratories and 1 ts development should be initiated.

2. An Executive Summary including findings and proposed actions of tho workshops and recommendations of the Conference should be prepared as quickly as possible.

The following recommendations were moved, discussed and passed by the Conference participants. 
1. ASTM should, without delay, bost a working group of organizations clearly identified as concerned with laboratory accreditation and with principal emphasis on construction materials testing. The charge to the working group should be to define the goals, scope, format and procedures of such a coordinated laboratory accreditation system. Participation in the working group should be by special invitation to individuals from organizations such as: AALA, AASHTO, AMRL, ASCE, CABO, CCRL, DOD, EFL/FCPA, FHWA, GSA, HUD, NBS, NCSBCS, NVLAP and WACEL. Efforts should be made to keep this group small and thus assure that everyone is heard and progress is furthered. Wayne Ellis was recommended as the chairman of the working group if he would agree to serve. A small planning group to organize the meeting should be established consisting of the chairman and representatives of groups such as AALA, AASHTO, ASTM and NBS. The organizers of this Conference should take a lead role in assuring that the working group meeting on the development of a coordinated laboratory accreditation system is expedited to maintain the momentum from this Conference.

2. NVLAP should not move forward to establish an independent laboratory accreditation program for construction materials but, instead, NVLAP officials should enter the dialogue with sponsors of this Conference and help develop a coordinated laboratory accreditation system.

3. CCRL and AMRL should not move forward to establish an independent laboratory accreditation program but, instead, CCRL and AMRL officials should enter the dialogue with sponsors and help develop a coordinated laboratory accreditation system for construction materials. 



\begin{abstract}
APPENDIX A
Conference Organizing Committee
\end{abstract}

Walter E. Capper

E. L. Conwell \& Company

Emery Farkas

W. R. Grace Company

Richard D. Gaynor

National Sand and Gravel Association/

National Ready Mixed Concrete Association

Richard E. Hay

Federal Highway Administration

Walter E. Runze

Portland Cement Association

Joseph F. Lamond

U.S. Army Corp of Engineers

James H. Plelert

National Bureau of Standards

Louis U. Spellman

Blue Circle/Atlantic Cement

Garland W. Steele

West Virginia Department of Highways 

Appendix B

Conference on Accreditation of Construction Materials Testing Laboratories

\section{PROGRAM}

May 14,1986

8:00 a.m. Registration (Coffee and Danish in Employees Lounge)

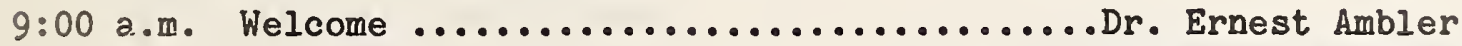

Director, National Bureau of Standards

9:10 a.m. Conference Chairman Remarks ............... Walter Kunze

Chairman, ASTM Joint C1/C9

Subcommittee on the CCRL

9:25 a.m. ASTM and Laboratory Accreditation ........Mr. Peter Brown

Vice President, Finance and Administration, ASTM

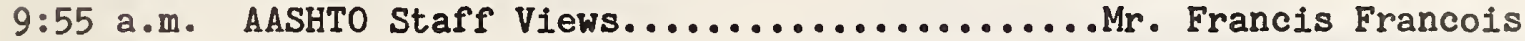

Executive Director, American Association of State Highway and Transportation Officials

$10: 20$ a.m. Coffee (Employees Lounge)

$10: 40 \mathrm{a} \cdot \mathrm{m}$. National and International Standards Activities Related to Laboratory Accreditation ........................... John Locke Chairman, ASTM Committee E-36

11:10 a.m. Status of ASTM Standard E329 and Other Related Standards................... Spencer Thew

Chairman, ASTM Subcommittee E36.93

11:40 a.m. Status of NVLAP Activities Related

to Construction Materials................. Robert Gladhill

Project Leader, National Voluntary Laboratory Accreditation Program

12:05 p.m. Status of AALA Activities Related to Construction Materials................. John Locke

Executive Director, American Association for Laboratory Accreditation

12:30 p.m. Accreditation of Testing

Laboratories in Florida................. John Roebuck

Member, Engineering Laboratories

Forum/Florida Concrete and

Products Association

1:00 p.m. Lunch (NBS Cafeteria)

1:55 p.m. Construction Materials Reference

Laboratories at NBS.

Mr. James Pielert

Group Leader, Construction

Materials Reference Laboratories

B-1 
2:20 p.m. Laboratory Accreditation from the

Perspective of a Construction

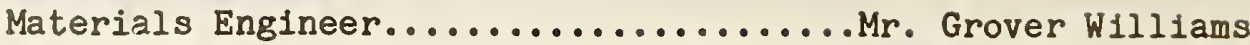

American Council of Independent

Laboratories

2:45 p.m. Laboratory Accreditation from the

Perspective of a Model Building

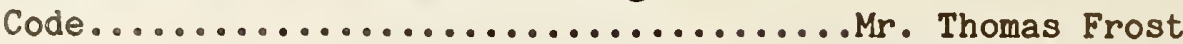

Manager, Evaluation Services, Building officials and Code Administrators International, Inc.

3:10 p.m. Coffee (Employees Lounge)

3:30 p.m. Laboratory Accreditation from the

Perspective of State Building

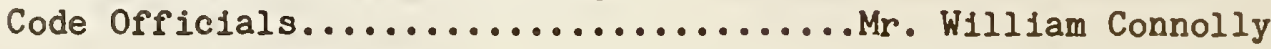

National Conference of States on Building Codes and Standards

3:55 p.m. Legal and Liability Concerns Associated with Certification and Accreditation Programs................... James Anderson

Partner, Loomis Owen Fellman and Howe

4:20 p.m. Certification Program Experiences

Relative to Liability Issues.............. Richard Gaynor

Executive Vice President

National Sand and Gravel

Association/National Ready-Mixed

Concrete Association

and

Mr. George Krepel, Jr.

Manager of Production Programs,

Prestressed Concrete Institute

5:00 p.m. Conference Chairman Remarks

5:30 p.m. Reception and Dinner at NBS Senior Lunch Club

7:00 p.m. Workshop Sessions at NBS

9:00 p.m. Adjournment for Evening

May 15, 1986

9:00 a.m. Reconvening of Workshop Sessions (Coffee and Danish ava1lable)

$10: 30$ a.m. Coffee

10:50 a.m. Continuation of Workshop Sessions

1:00 p.m. Lunch (NBS Cafeteria)

2:00 p.m. Reports of Workshop Cha1rmen

5:00 p.m. Concluding Remarks by Conference Cha1rman

5:15 p.m. Conference Adjournment 
James Anderson

Loomis, Owen, Fellman \& Howe

2020 K Street, N.W.

Washington, DC 20006

Phone: 202 296-5680

Workshop No.: 1

Michael S. Anselmo

United States Testing Co., Inc.

1415 Park Avenue

Hoboken, NJ 07030

Phone: 201 792-2400

Workshop No.: 2

John D. Antrim, General Manager NICET

1420 King Street

Alexandria, VA 22314

Phone: 703 684-2835

Workshop No.: 3

Harvey Berger

National Bureau of Standards

Admin. Bldg. Rm. A531

Gaithersburg, MD 20899

Phone: 301 921-3431

Workshop No.: 2

Joseph Berke

Naval Civil Engineering Lab.

Code L-53

Port Hueneme, CA 93043

Phone: 805 982-5555

Workshop No.: 4

Joe Bhatia \& Hank Collins

Underwriters Laboratories

81818 th Street

Washington, DC 20006

Phone: 202 296-7840

Workshop No.: 3

\section{W. Britzius}

Twin City Testing Co.

622 Cromwel1

St. Paul, MN 55114

Phone: 612 645-3601

Workshop No.: 1
Peter Brown

ASTM

1916 Race St.

Philadelphia, PA 19103

Phone: 215 299-5400

Workshop No.: 2

Conway C. Burton

Chicago Testing Laboratory, Inc.

3360 Commercial Ave.

Northbrook, IL 60062

Phone: 312 498-6400

Workshop No.: 3

Walter E. Capper

E. L. Conwel1 \& Co.

Continental Business Cen.

Front \& Ford Streets

Bridgeport, PA 19405

Phone: 215 277-2402

Workshop No.: 1

Michael A. Clark

American Concrete Institute

22400 W. Seven Mi.Rd

Detroit, MI 48219

Phone: 313 532-2600

Workshop No.: 4

William Connolly

State of New Jersey

363 W. State St.

P. O. Box CN804

Trenton, NJ 08625

Phone: 609 292-7899

Workshop No.: 1

Gary L. Cooper, Assistant State Engr Arizona DoT

Room 127A

206 S. 17th Ave.

Phoenix, AZ 85007

Phone: 602 255-7286

Workshop No.: 2

Charles Culver

NBS

Structures Division

Bldg. 226, Rm. B268

Gaithersburg, MD 20899

Phone: 301 921-2196

Workshop No.: 1 
Richard Davidson

HQ - Corps of Engineers

DAEN - ECE-G

Washington, DC 20314-1000

Phone: 202 272-0207

Workshop No.: 3

Calvin L. Dodl

Froehling \& Robertson

3015 Dumbarton Road

Richmond, VA 23228

Phone: 804 264-2701

Workshop No.: 3

Kingsley D. Drake, Executive V.P.

PTL Inspectorate, Inc.

850 Poplar St.

Pittsburgh, PA 15220

Phone: $412922-4000$

Workshop No.: 4

Rolland Drouin, Committee Member

Standards Council of Canada

123 Jean Proulx

Hull, Quebec, Canada J8X 1 T4

Phone: $819778-1770$

Workshop No.: 4

Wayne P. Ellis, Standards Consultant 754 Bobbea Lane

Harleysville, PA 19438

Phone: 215 628-2600

Workshop No.: 1

\section{Emery Farkas}

W. R. Grace \& Co.

62 Whittemore Ave.

Cambridge, MA 02140

Phone: $617876-1400$

Workshop No.: 2

Frank Fee, Manager Tech. Serv.

West Bank Oil

P. 0. Box 638

Pennsauken, NJ 08110

Phone: 609 428-8808

Workshop No.: 2
Lynne Fitzpatrick, Director

National Research Council

2101 Constitution

Washington, DC 20418

Phone: 202 334-3137

Workshop No.: 2

Thomas Flint, Director, Tech.Serv. American Plywood Association

P.0. Box 11700

Tacoma, WA 98411

Phone: 206 565-6600

Workshop No.: 2

J. R. Forbes

Law Engineering

P.O. Box 888013

Atlanta, GA 30352

Phone: 404 396-8000

Workshop No.: 3

Colin A. Franco

Rhode Island DoT

372 State Office Bldg.

Smith Street

Providence, RI 02903

Phone: 401 277-2525

Workshop No.: 4

Francis B. Francois, Executive Director AASHTO

444 N. Capitol St. NW

Washington, DC 20001

Phone: 202 624-5800

Workshop No.: 0

John H. Frank

Certified Testing Labs., Inc.

1105 Riverbend Dr.

Dalton, GA 30720

Phone: 404 226-1400

Workshop No.: 0

\section{Geoffrey Frohnsdorff}

NBS

Bldg. 226, Rm. B368

Gaithersburg, MD 20899

Phone: 301 921-3704

Workshop No.: 3 
Thomas Frost, Manager, Eval. Serv. BOCA, International 4051 W. Slossmoor Rd

Country Club H., IL 60430

Phone: 312 799-2300

Workshop No.: 4

J.E. Galloway, Jr.

VA Dept. of Hwys. \& Transp.

1221 East Broad St.

Richmond, VA 23219

Phone: 804 737-7731

Workshop No.: 3

Richard D. Gaynor

NSGA - NRMCA

900 spring st.

Silver Spring, MD 20910

Phone: 301 587-1400

Workshop No.: 3

\section{Robert Gladhill}

NBS

Admin. B1dg., A531

Gaithersburg, MD 20899

Phone: 301 921-3431

Workshop No.: 4

\section{Roger Goughnour}

Federal Highway Administration Cons. \& Maint. Div.

4007 th St., SW

HHO 33

Washington, DC 20590

Phone: 202 426-6520

Workshop No.: 1

James G. Gross, Dep. Director Center for Building Technology NBS

B1dg. 226, Rm. A250

Gaithersburg, MD 20899

Phone: 301 921-3481

Workshop No.: 2

W. G. Gunderman

Transportation Research Board

National Academy Sciences

2101 Constitution Av

Washington, DC 20418

Phone: 202 334-2952

Workshop No.: 4
Mukand V. Handa

Canadian Standards Association

178 Rexdale Blvd.

Rexdale, Ontario, Canada M9W 1R3

Phone: 416 747-4255

Workshop No.: 2

Rodney B. Hawkins

Inland Steel

3210 Watling

Mail Code 2101

East Chicago, Indiana 46312

Phone: 219 392-3271

Workshop No.: 3

R. E. Hay, Director, R\&D

Federal Highway Admin, HNR-1

6300 Georgetown Pike

McLean, VA 22101

Phone: 703 285-2001

Workshop No.: 4

D. J. Hensing, Dep. Ex. Director

AASHTO

Suite 225

444 N. Capitol N.W.

Washington, DC 20001

Phone: 202 624-5800

Workshop No.: 4

Charles W. Hyer

The Marley Organization, Inc.

11 Todd's Road

Ridgefield, CT 06877-9990

Phone: 203 438-3801

Workshop No.: 1

Claude E. Jaycox

Municipal Testing

160 Lauman Lane

Hicksville, NY 11801

Phone: 516 938-7120

Workshop No.: 2

Ralph E. Jenkins

Core Laboratories

7501 Stemmons Frwy.

Dallas, TX 752:7

Phone: 214 631-8270

Workshop No.: 3 
Kenneth Keeling

The Robert B. Balter Co.

7646-B Fullerton Rd.

Springfield, VA 22153

Phone: 703 569-3050

Workshop No.: 3

Paul Klieger

Portland Cement Assoc.

5420 Old Orchard Rd.

Skokie, IL 60077

Phone: 312 966-6200

Workshop No.: 1

Paul Knodel

Bureau of Reclamation

D1540

P. O. Box 25007

Denver, CO 80225

Phone: 303 236-8098

Workshop No.: 4

William C. Koehler

Pennsylvania DoT

Materials \& Testing Div.

1118 State St.

Box 2926

Harrisburg, PA 17120

Phone: 717 783-8417

Workshop No.: 1

Raymond M. Kolos

CCRL-NBS

National Bureau of Stand.

Bldg. 226 Rm. A365

Gaithersburg, MD 20899

Phone: 301 921-3481

Workshop No.: 1

George Krepel

Prestressed Concrete Institute

201 N. Wells Street

Chicago, IL 60606

Phone: 312 346-4071

Workshop No.: 2

Walter E. Kunze

Portland Cement Association

5420 Old Orchard Rd.

Skokie, IL 60077

Phone: 312 966-6200

Workshop No.: 1
Joseph F. Lamond

HQ - Corps of Engineers

DAEN - ECE - D

Washington, DC 20314-1000

Phone: 202 272-0222

Workshop No.: 2

John Locke

Amer. Assoc. for Lab. Accreditation 656 Quince Orchard

Gaithersburg, MD 20878

Phone: 301 670-1377

Workshop No.: 3

Hugh MacDonald

Brick Institute of America

Suite 300

11490 Commerce $\mathrm{Pk}$ Dr

Reston, VA 22091

Phone: 703 620-0010

Workshop No.: 4

Malcolm MacLean

Ministry of Transp. and Communica.

Central Bldg. Room 309

120 Wilson Ave.

Downsview, Ontario M3M $1 \mathrm{~J} 8$

Phone: 416 248-3696

Workshop No.: 1

Frank Malbroda

VSE Corporation

2550 Hunington Ave.

Alexandria, VA 22303

Phone: $703960-4600$

Workshop No.: 2

G. W. Maupin, Jr.

VA Hwy. \& Transp. Research Council

University Station

Box 3817

Charlottesville, VA 22903-0817

Phone: 804 296-1948

Workshop No.: 3

John Melander

Riverton Corporation

Rt 637

P. 0. Box 300

Riverton, VA 22651

Phone: 703 635-4131

Workshop No.: 4 
Cyril M. Miller

U.S. Army Corps of Engrs.

Baltimore District

P. 0. Box 1715

Baltimore, MD 21203

Phone: $301962-3164$

Workshop No.: 4

Joseph O'Neil

American Council of Independ. Labs .

$1725 \mathrm{~K}$ Street N.W.

Washington, DC 20006

Phone: 202 887-5872

Workshop No.: 3

\section{Terry Patzias}

Dundee Cement Co.

P. 0. Box 122

Dundee, MI 48104

Phone: 313 529-2411

Workshop No.: 1

John T. Paxton, P.E.

Ohio Department of Transportation

Bureau of Testing

1600 W. Broad St.

Columbus, OH 43223-1298

Phone: 614 275-1301

Workshop No.: 2

\section{Adrian Pelzner}

U.S. Forest Service

2704 Soapstone Drive

Reston, VA 22091

Phone: 703 860-0027

Workshop No.: 1

James H. Pielert, Group Leader Construction Materials Ref. Labs NBS

Bldg. 226, Room A365

Gaithersburg, MD 20899

Phone: 301 921-3481

Workshop No.: 2

\section{Maxie Pruitt}

Tri-County Concrete Corp.

Carolina's Ready-Mix Asso

P. O. Box 9097

Hanahan, SC 29410

Phone: $803744-5731$

Workshop No.: 3
Paul S. Quigg, Sr. Research Assoc.

USG Corporation

700 North Highway 45

Libertyville, IL 60048

Phone: $312362-9797$

Workshop No.: 4

Michael Rafalowski

Federal Highway Administration

Construction \& Maint. Div

4007 th St., SW

HHO 33

Washington, DC 20590

Phone: 202 426-0436

Workshop No.: 1

Thomas Ridgway

DMSSO

Suite 1403

2 Skyline P1.

Falls Church, VA 22043

Phone: 703 756-2343

Workshop No.: 2

John P. Roebuck

Florida Mining \& Materials Cons.

P.0. 23965

Tampa, FL 33630

Phone: 813 933-6711

Workshop No.: 3

Thomas R. Rutherford, P.E.

NAVFAC 04M2

200 Stovall St.

Alexandria, VA 22332

Phone: $202325--356$

Workshop No.: 4

John M. Scanlon

USA Corps of Engineers

Waterways Exp. Sta.

P.0. Box 631

Vicksburg, MS 39180

Phone: 601 634-3277

Workshop No.: 1

James R. Scarazzo

The Robert B. Balter Co.

7646-B Fullerton Rd.

Springfield, VA 22153

Phone: 703 569-3050

Workshop No.: 2 
Brian Sheffler

Phoenix, Inc.

P.O. Box 676

Frederick, MD 21701

Phone: 301 663-3129

Workshop No.: 3

Lawrence L. Smith, Mtls. \& Res. Engr. Florida DoT - BM\&R 2006 N.E. Waldo Rd. P. O. Box 1029

Gainesville, FL 32602

Phone: 904 372-5304

Workshop No.: 4

David A. Smith, Jr. City of Akron, Ohio Building Inspection Dept.

166 S. High St. R100

Akron, $\mathrm{OH} 44308$

Phone: 216 375-2220

Workshop No.: 1

Peter A. Spellerberg AASHTO Materials Reference Lab. National Bureau of Stds.

Bldg. 226, Rm. A365

Gaithersburg, MD 20899

Phone: 301 921-3481

Workshop No.: 3

L. U. Spellman

Apt. 115

2918 Ranch Rd. $620 \mathrm{~N}$

Austin, TX 78734

Phone: 512 266-3533

Workshop No.: 3

Garland W. Steele

West Virginia Dept. of Highways

1900 Washington St.E

Charleston, WV 25301

Phone: 304 348-3100

Workshop No.: 4

R. J . Stephenson, Director

U.S. Army Corps of Engineers

S. Atlantic Div. Lab.

611 South Cobb Dr.

Marietta, GA 30060-3112

Phone: 404 429-5296

Workshop No.: 2
Frank M. Stia

New Jersey DoT

999 Parkway Ave.

Trenton, NJ 08255

Phone: 609 292-3461

Workshop No.: 3

Spencer F. Thew

Atlantic Testing Labs, Ltd.

Box 29

Canton, NY 13617

Phone: 315 386-4578

Workshop No.: 4

Frank T. Wagner

North Carolina DoT

P.O. Box 25201

Raleigh, NC 27611

Phone: 919 733-7411

Workshop No.: 1

Marc Walsh, Staff Member

Standards Council of Canada

Suite 1203

350 Sparks St.

Ottawa, Ontario, Canada KIR 7S8

Phone: $613238-3222$

Workshop No.: 2

Marvin S. Ward, Jr.

Carolinas Ready Mixed Concrete

P. 0. Box 11064

Charlotte, NC 28220

Phone: 704 525-2180

Workshop No.: 3

Charles Whitcomb

The Robert B. Balter Co.

7646-B Fullerton Rd.

Springfield, VA 22153

Phone: 703 569-3050

Workshop No.: 4

Grover C. Williams

Trinity Engineering Testing Corp.

3601 Manor Road

Austin, TX 78723

Phone: 512 926-6650

Workshop No.: 1 


\section{Appendix D \\ Guidelines for Workshop Chairmen}

Each workshop will have approximately six hours to work together following the presentation of prepared talks. The workshops will begin work on the evening of May 14th at 7:00 p.m. and continue until 9:00 p.m. It is anticipated that this time will be taken to introduce the subject matter, prepare an outline of the potential topics to be discussed, plan on how best to carry out activity, and to initiate indepth discussion. The workshop session on the morning of May 15 from 9:00 a.m. until 1:00 p.m. will be for indepth discussion of the issues and the development of conclusions and recommendations for presentation to the full conference.

Each workshop room will be provided with a viewgraph, flip charts, blackboard space, and a staff support person to assist the chairman. The chairman should select a workshop participant to keep the record of the discussions and conclusions. There will be no recording of the workshop proceedings. The conclusions and recommendations of the workshop will be summarized in a report which will be delivered by the chairman to the full conference on the afternoon of May 15th. The prepared talks and the workshop reports will be recorded. Typing support will be available to assist in preparing the reports.

Each Workshop is to address the Conference hypothesis that "There is a need for a coordinated methodology for accrediting construction materials testing laboratories." The following issues are suggested for workshops consideration:

I. Current methodology that may effect performance in construction material testing laboratories

- indicators pointing out where changes in methodology may improve laboratory performance

- relationship of laboratory testing to overall quality of construction

- use of more than one standard for identical type testing (e.g. ASTM and AASHTO)

II. Analysis of currently operating evaluation/accreditation systems for construction materials

- review of the current evaluation/accreditation systems (CCRL, AMRL NVLAP, AALA, ELF/FCAA, WACL, etc.)

- impact of current laboratory evaluation/accreditation systems on laboratory performance

- factors affecting the acceptance of current evaluation/ accreditation systems (e.g. cost, scope of coverage, lack of regulatory reference, lack of economic benefit)

- the adequacy of current standards (both national and international) on the implementation and acceptance of laboratory evaluation/ accreditation programs 
III. Is there a need for a coordinated laboratory-accreditation system or is the current approach adequate?

- review of approach recommended by ASTM Panel on Accreditation, NVLAP Construction Materials Testing LAP, etc.

IV. If needed, what are the components and approach for implementation of such a coordinated system?

- level of accreditation depending upon the scope of services offered by the laboratory

- review by broad technical (e.g. construction materials) discipline vs. review by standards for specific materials

- scope of in-laboratory evaluation

- review of apparatus and/or procedures

- reliance on professional engineer in charge of laboratory

- adequacy of available standards on laboratory accreditation

- implementation of ASTM laboratory evaluation type standards being developed

- format of certificate of accreditation

V. Approach for gaining acceptance of a coordinated accreditation system

- promotion of regulatory references requring use of evaluation/ accreditation systems

- emphasis on the benefits of laboratory accreditation programs to the construction community to justify the costs 
NBS.114A (REV. 2.8C)

\begin{tabular}{|c|c|c|c|}
\hline $\begin{array}{r}\text { U.S. DEP T. OF COMM. } \\
\text { BIBLIOGRAPHIC DATA } \\
\text { SHEET (See instructions) }\end{array}$ & $\begin{array}{c}\text { 1. PUBLICATION OR } \\
\text { REPORT NO. } \\
\text { NBSIR-86/3397 }\end{array}$ & & JUNE \\
\hline
\end{tabular}

4. TITLE AND SUBTITLE

Executive Summary - Conference on Accreditation of Construction Materials Testing Laboratories, May 14-15, 1986

\section{AUTHOR(S)}

James H. Pielert

6. PERFORMING ORGANIZATION (If joint or other than NBS, see instructions)

7. Contrac/Grant No.

NATIONAL BUREAU OF STANDARDS

DEPARTMENT OF COMMERCE

WASHINGTON, D.C. 20234

8. Type of Report \& Period Covered

9. SPOHSORING ORGANIZATHON NAME AND COMPLETE ADDRESS (Street, CHE, StOte, ZIF)

American Society for Testing and Materials

1916 Race Street

Philadelphia, PA 19103

10. SUPPLEMENTARY NOTES

[Document describes a computer program; SF-185, FIPS Software Summary, is attached.

11. ABSTRACT (A 200-word or less factual summary of most significant information. If document includes a significant bibliography or literature survey, mention it here)

A two-day conference hosted by NBS was held in Gaithersburg, Maryland on May 14-15, 1986 to test the hypothesis that "there is a need for a coordinated methodology for accrediting construction materials testing laboratories." Construction materials include the primary materials such as: cement, concrete aggregates, rock and soil, asphalts, metals, wood and masonry. The conference was structured to consider: (i) the status of existing laboratory evaluation and accreditation programs; (2) current trends in the accreditation process; and (3) the need for and nature of a coordinated accreditation system. Conference format included the presentation of invited papers and four workshop sessions. This Executive Summary presents the findings and proposed actions of the workshop and the conference recommendations. Conference proceedings will be published later.

12. KEY WORDS (Six to twelve entries: alphabetical order: capitalize only proper names: and separate key words by semicolons) accreditation; construction; laboratory; materials; standards

[X] Unlimited

$\square$ For Official Distribution. Do Not Release to NTIS

$\square$ Order From Superintendent of Documents, U.S. Government Printing Office, Washington, D.C. 20402.

14. NO. OF

PRINTED PAGES

27

15. Price

[X] Order From National Technical Information Servlce (NTIS), Springfield, VA. 2216I 


